\title{
Phase, Microstructure and Beneficiation of Manganese Ore by Acid Leaching
}

\author{
Sajad Ali*, Yaseen Iqbal, Kamran Ahmad, Billal Afridi \\ Materials Research Laboratory, Department of Physics, University of Peshawar, Peshawar, Pakistan \\ Email: *sajjad2485@yahoo.com
}

How to cite this paper: Ali, S., Iqbal, Y., Ahmad, K. and Afridi, B. (2018) Phase, Microstructure and Beneficiation of Manganese Ore by Acid Leaching. Journal of Minerals and Materials Characterization and Engineering, 6, 60-71.

https://doi.org/10.4236/jmmce.2018.61006

Received: May 25, 2017

Accepted: January 26, 2018

Published: January 29, 2018

Copyright $\odot 2018$ by authors and Scientific Research Publishing Inc. This work is licensed under the Creative Commons Attribution International License (CC BY 4.0).

http://creativecommons.org/licenses/by/4.0/

\begin{abstract}
In this research work, sawdust was used as a reducing agent for sulphuric acid leaching of manganese ore from Prang Ghar, Lower Mohmand Agency, Pakistan. X-ray diffraction of the powdered sample indicated the presence of Hausmannite $\left(\mathrm{Mn}_{3} \mathrm{O}_{4}\right)$, Calcium Aluminum Silicate Hydrate, Silica $\left(\mathrm{SiO}_{2}\right)$ and Hematite $\left(\mathrm{Fe}_{2} \mathrm{O}_{3}\right)$. X-ray diffraction and the energy dispersive spectroscopic analysis show that the manganese ore sample was siliceous in nature. In the present study, six process parameters were investigated i.e. the particle size of the ore, leaching temperature, time duration, Mn ore amount, sulphuric acid concentration and amount of sawdust. Manganese extraction of 88.93 (wt\%) was achieved for a leaching time of 60 minutes at $120^{\circ} \mathrm{C}$ using $5 \%(\mathrm{v} / \mathrm{v}) \mathrm{H}_{2} \mathrm{SO}_{4}$ concentration for $10 \mathrm{~g} \mathrm{Mn}$ ore and $5 \mathrm{~g}$ sawdust. The results demonstrate that sawdust is a low cost, renewable and non-hazardous reducing agent in comparison to other available reagents.
\end{abstract}

\section{Keywords}

Siliceous Manganese Ore, Characterization, Leaching, Sawdust, Sulfuric Acid

\section{Introduction}

Manganese is an important element with a number of uses in major industrial applications i.e. production of steel, preparation of dietary additives, fertilizers, dry cells, paint production, animal feeds, textile dyes, medicines and colorants for bricks. Low-grade manganese ore can be treated either by reductive roasting or by reductive acid leaching [1] [2] [3]. Depletion of high grade Mn-ore has forced industry to use low and medium grade ore as raw material for the growing demands of steel and chemical industry. Since manganese dioxide ores are highly stable in acidic or alkaline oxidizing conditions, therefore its extraction should be carried out in reducing environment [2]. 
Using glucose as reducing agent in dilute nitric acid medium at $90^{\circ} \mathrm{C}$ for $32 \mathrm{~h}$, 99\% manganese has been extracted. It is concluded that high grade manganese can be obtained using nitric acid instead of sulphuric acid [4]. Kelong et al., reported that using sawdust and rice husk as reductant in sulphuric acid medium, 95\% manganese can be leached out. The influencing factors included pyrolusite and plant powder charge, sulphuric acid volume, temperature and duration of leaching [5]. Hariprasad et al., reported that $\sim 98 \%$ manganese can be extracted after leaching for $8 \mathrm{~h}$ using sawdust as reducing agent in sulphuric acid medium. Optimum leaching was reported for $5 \% \mathrm{H}_{2} \mathrm{SO}_{4}(\mathrm{v} / \mathrm{v})$ and $5 \%$ sawdust (w/w) at $90^{\circ} \mathrm{C}[6]$.

Using cane molasses as reducing agent in nitric acid medium raises manganese content from $37.5 \%$ to $\sim 98 \%$ at optimum conditions of $2.7 \mathrm{M} \mathrm{HNO}_{3}$, cane molasses $20 \%$ by weight, grain size $74 \mu \mathrm{m}$, solid/liquid ratio $1: 12$ for $2 \mathrm{~h}$ at $95^{\circ} \mathrm{C}$ [7]. Some biomass wastes such as sawdust, cane molasses, corncob, cornstalks, rice husk, wheat stalks, bagasse, bamboo, and shredded paper are environmentfriendly and low-cost reducing agents for roasting reduction and leaching of manganese dioxide ore [8] [9].

In the present work, sawdust was used as a reducing agent in dilute sulfuric acid medium to extract manganese from ferromanganese ores. The use of sawdust for reduction of manganese dioxide is a simple, low cost and economical method in comparison to the other reductants.

\section{Materials and Methods}

Representative sample of manganese ore was collected from Prang Ghar $\left(34^{\circ} 25^{\prime} \mathrm{N}, 71^{\circ} 37^{\prime} 3^{\prime \prime E}\right)$, Upper Mohmand Agency, Khyber Pukhtunkhwa (KP), Pakistan. Manganese ore was crushed, grinded and then passed through 149 and 74 $\mu \mathrm{m}$ sieves. Semi-quantitative EDS detected 24.05 wt\% Mn, 21.15 wt\% Ca, 15.24 wt $\% \mathrm{Si}, 6.87 \mathrm{wt} \% \mathrm{Al}, 29.44 \mathrm{wt} \% \mathrm{Fe}$ and $3.25 \mathrm{wt} \% \mathrm{Mg}$ in as-mined ore sieved at $74 \mu \mathrm{m}$.

The leaching experiments were performed in a $500 \mathrm{~mL}$ glass beaker kept on a ceramic hot plate and magnetic stirring system in a fume hood. Initially $100 \mathrm{~mL}$ solution $5 \%(\mathrm{v} / \mathrm{v}) \mathrm{H}_{2} \mathrm{SO}_{4}\left(5 \mathrm{~mL} \mathrm{H}_{2} \mathrm{SO}_{4}\right.$ and $95 \mathrm{~mL}$ distal water) was mixed thoroughly with weighed amount of sawdust (3,4 and $5 \mathrm{~g}$ ) to release glucose into the acid. After $15 \mathrm{~min}$, the weighed amount of ore powder was transferred to the pulp. The leaching experiments were carried out for different sets of parameters i.e. particle size of Mn ore, leaching temperature, leaching time, Mn ore amount, sulphuric acid concentration and amount of sawdust.

Room temperature $\mathrm{X}$-rays diffraction $(\mathrm{XRD})$ data were recorded using a JEOL JDX-3532 X-ray diffractometer, operating at $40 \mathrm{kV}$ and $30 \mathrm{~mA}$, with $\mathrm{Cu} \mathrm{K} \alpha$ radiation $(\lambda \sim 0.154 \mathrm{~nm})$ at Centralized Resource Laboratory (CRL), University of Peshawar, Pakistan. The samples were scanned from $10^{\circ}-70^{\circ}(2 \theta)$ with a count time/step of $1.25 \mathrm{~s}$ and $0.02^{\circ}$ step size. Secondary electron scanning electron microscope (SEM) images of chemically etched samples were recorded using a 
JEOL JSM5910 SEM, operating at $30 \mathrm{keV}$. Semi-quantitative energy dispersive $\mathrm{X}$-ray electron spectroscopy (EDS) data were collected using an INCA200 EDS detector (Oxford instruments, UK), connected with a JEOL-JSM5910 SEM. A PMG-3 microscope coupled with a DP-12 CCD camera, Olympus (Japan) was used for recording optical images in the present study at CRL.

\section{Results and Discussion}

\subsection{Characterization of As-Mined Samples}

Figure 1 shows the reflected light micrograph of as-mined manganese ore sample. Three types of micro-regions were observed to have different contrast, microstructure and texture.

The long and straight dark thick strip marked as "A" crossing two different types of regions (appearing light greenish dark region with granular morphology and the plane white region) may be due to the combination of oxides of manganese and iron that impart iron black color [2]. The white to bluish grey colored micro-regions marked as B and C may be the maghemite (iron rich) phase as it gives rise to a similar color/contrast under reflected light [3]. The boundaries of the micro-regions $\mathrm{B}$ and $\mathrm{C}$ were sharp and could be distinguished from one another.

Figure 2 shows a secondary electron SEM image (SEI) of as-mined ore sample showing three distinct micro-regions. Light grey irregular shape manganese rich micro-regions with spongy texture marked as A and C. The light grey cuboidal

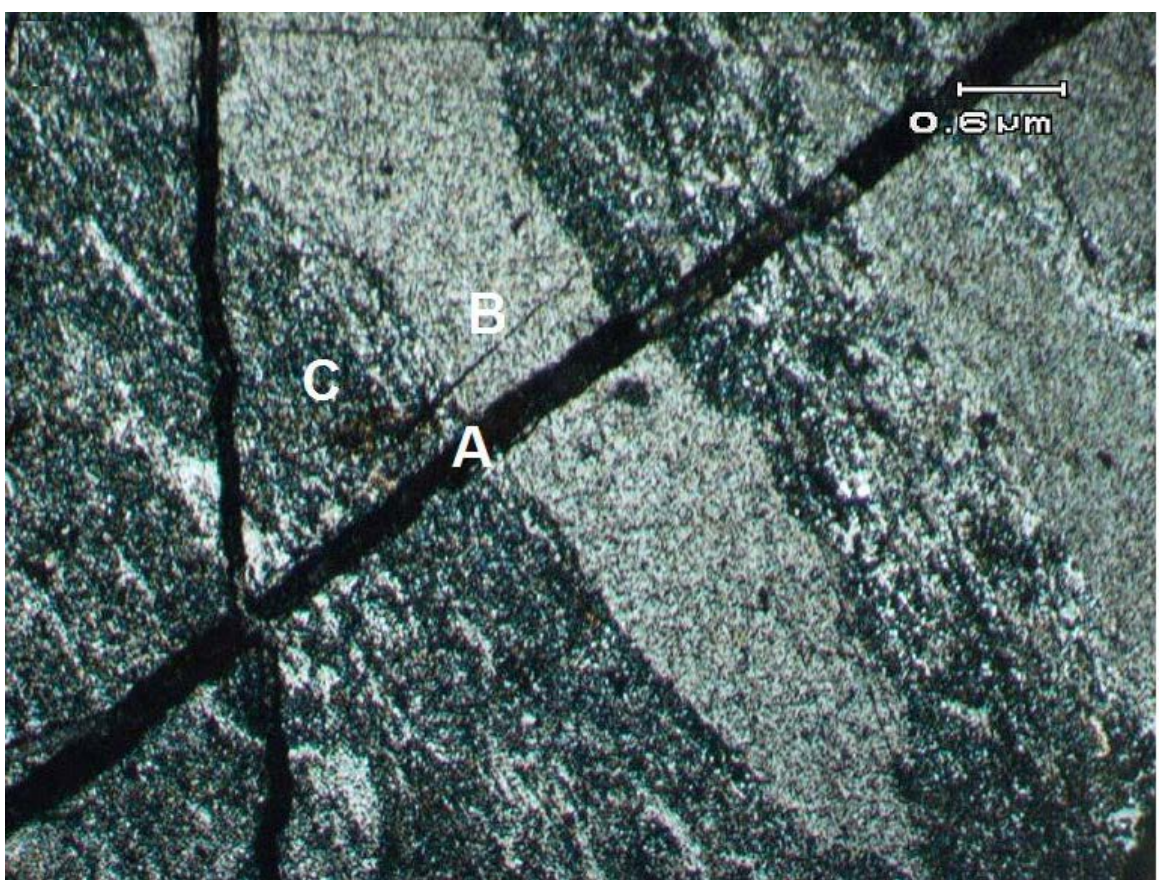

Figure 1. Reflected light micrograph of as-mined manganese ore sample showing microregions with different morphology and appearance. Long and jet dark strips marked as " $A$ " is $\mathrm{Mn}$ rich while white to bluish grey micro-regions marked as " $\mathrm{B}$ " and " $\mathrm{C}$ " may be due to iron rich maghemite. 


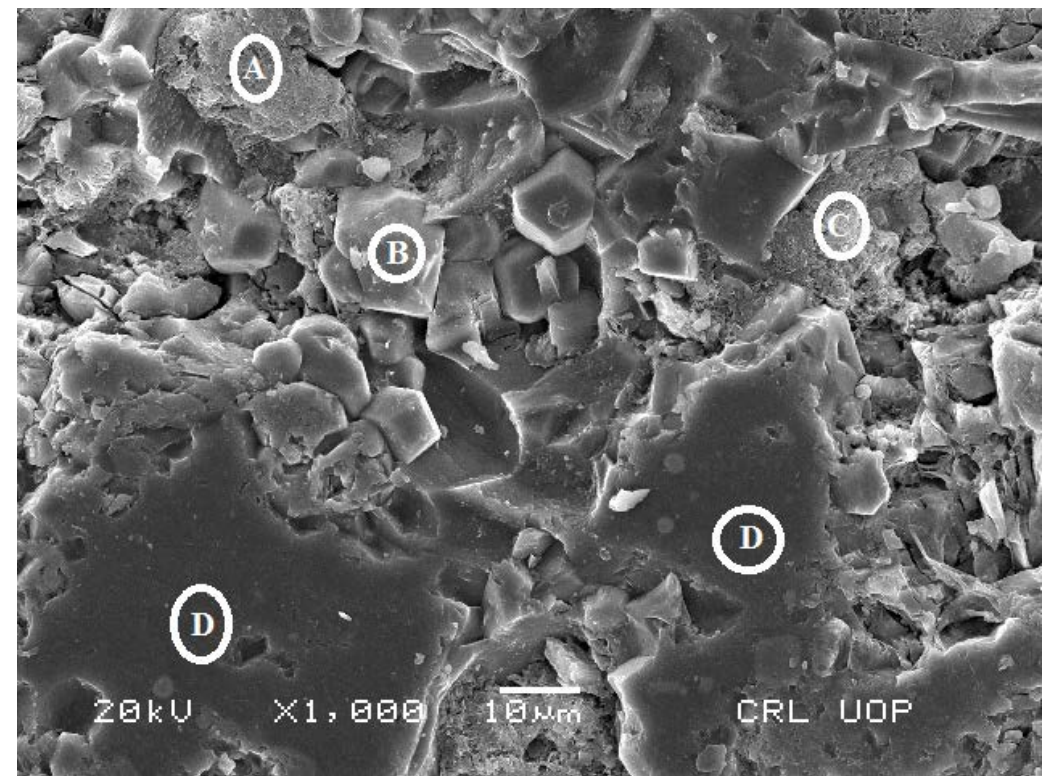

Figure 2. SEI of as-mined manganese ore sample showing different micro-regions, manganese rich micro-region marked as A \& $\mathrm{C}$, pure silica region with blackish appearance marked as D and cuboidal grain marked as B.

Table 1. Elemental composition of different micro-regions shown in Figure 2.

\begin{tabular}{ccccccc}
\hline \multirow{2}{*}{ Elements/Region } & \multicolumn{6}{c}{ Elemental concentration (wt\%) } \\
\cline { 2 - 7 } & $\mathrm{Mg}$ & $\mathrm{Al}$ & $\mathrm{Si}$ & $\mathrm{Ca}$ & $\mathrm{Fe}$ & $\mathrm{Mn}$ \\
\hline Gross composition & 3.25 & 6.87 & 15.24 & 21.15 & 29.44 & 24.05 \\
A & ---- & ---- & 10.16 & 9.14 & 20.30 & 60.40 \\
B & ---- & 16.07 & 31.61 & 4.86 & 8.51 & 38.95 \\
C & ---- & 17.35 & 30.51 & 7.47 & $-\cdots--$ & 44.67 \\
D & ---- & ---- & 100 & ---- & $-\cdots--$ & --- \\
\hline
\end{tabular}

or pseudo-hexagonal grains labeled as B and dark grey silica rich plane microregion labeled as $\mathrm{D}$. The elemental compositions of these micro-regions are given in Table 1.

Figure 3 shows room temprature XRD pattern recorded for as-mined manganese ore. The inter-planner spacing (d-values) and relative intensities corresponding to the major XRD peaks (labled as a) recorded for manganese ore matched PDF \# 75-1560 for $\mathrm{Mn}_{3} \mathrm{O}_{4}$ indicating it to be the major phase in the examined sample. Additionally, some minor peaks (labeled as b, c and d) matched PDF \# 20-452 for Calcium Aluminum Silicate Hydrate, PDF\# 38-360 for $\mathrm{SiO}_{2}$ and PDF \# 6-502 for Hematite $\left(\mathrm{Fe}_{2} \mathrm{O}_{3}\right)$ showing these to be minor phases of gangue minerals. Table 2 shows a comparison of mineralogical and elemental analysis by XRD and EDS respectively.

Using XRD Cheng et al. reported the presence of pyrolusite $\left(\mathrm{MnO}_{2}\right)$ as the major phase along with small amounts of $\mathrm{MgO}$, silica $\left(\mathrm{SiO}_{2}\right)$, hematite $\left(\mathrm{Fe}_{2} \mathrm{O}_{3}\right)$ and $\mathrm{Al}_{2} \mathrm{O}_{3}$ in manganese ore from Guangxi, China [10]. Another XRD study of 


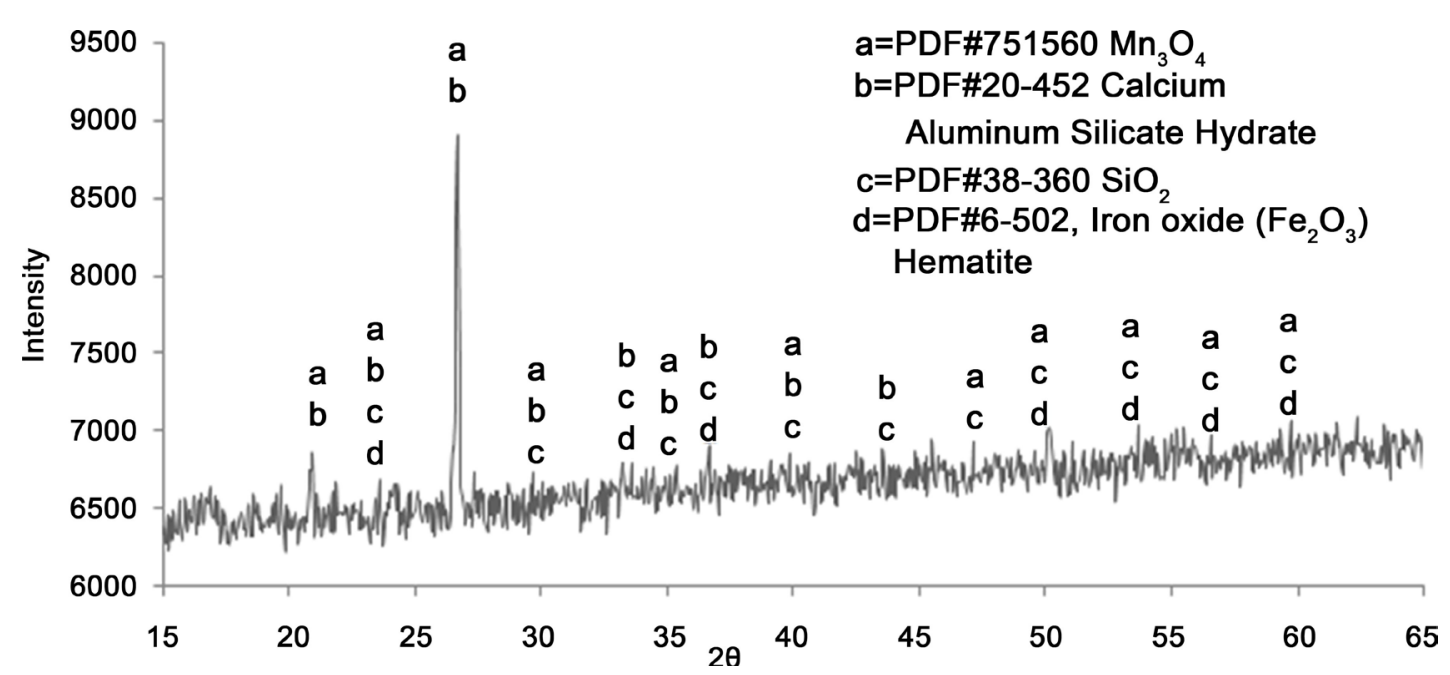

Figure 3. XRD patterns of as-mined manganese ore showing different phases marked as a, b, c \& d.

Table 2. Elemental and mineralogical analysis by EDS and XRD.

\begin{tabular}{ccccc}
\hline \multicolumn{4}{c}{ EDS analysis } & \multicolumn{3}{c}{ XRD analysis } \\
\hline Elements & $\mathrm{Wt} \%$ & Mineral & Formula & PDF \# \\
\hline $\mathrm{Si}$ & 15.24 & Quartz & $\mathrm{SiO}_{2}$ & $38-360$ \\
$\mathrm{Mn}$ & 24.05 & Hausmanite & $\mathrm{Mn}_{3} \mathrm{O}_{4}$ & $75-1560$ \\
$\mathrm{Fe}$ & 29.44 & Hematite & $\mathrm{Fe}_{2} \mathrm{O}_{3}$ & $6-502$ \\
$\mathrm{Al}$ & 2.87 & & & \\
$\mathrm{Ca}$ & 22.40 & Calcium aluminium silicate hydrate & $20-452$ \\
\hline
\end{tabular}

low-grade manganese ore from Guangxi, China reported the presence of todorokite $\left(\mathrm{Mn}_{6} \mathrm{O}_{12} \cdot 4 \cdot 16 \mathrm{H}_{2} \mathrm{O}\right)$ and hematite $\left(\mathrm{Fe}_{2} \mathrm{O}_{3}\right)$ as the major phases and the gangue minerals were quartz $\left(\mathrm{SiO}_{2}\right)$ and kaolinite $\left(\mathrm{Al}_{2} \mathrm{Si}_{2} \mathrm{O}_{5}(\mathrm{OH})_{4}\right)$ [11].

\subsection{Characterization of Leached Manages Ore Samples}

Basic chemical reaction for leaching of $\mathrm{MnO}_{2}$ using sawdust $\mathrm{C}_{6} \mathrm{H}_{10} \mathrm{O}_{5}$ can be as following

$$
12 \mathrm{MnO}_{2}+\mathrm{C}_{6} \mathrm{H}_{10} \mathrm{O}_{5}+12 \mathrm{H}_{2} \mathrm{SO}_{4} \rightarrow 12 \mathrm{MnSO}_{4}+17 \mathrm{H}_{2} \mathrm{O}+6 \mathrm{CO}_{2} \uparrow
$$

$\mathrm{C}_{6} \mathrm{H}_{10} \mathrm{O}_{5}$ show that cellulose of sawdust contain $\alpha$-D-glucose units. Acid treatment release glucose that acts as reducing agent [12].

\subsection{Effect of Mesh Size}

Influence of particle size of ore on efficiency of leaching was studied at 100, 200 and 300 mesh sizes while keeping the other parameters constant i.e. $5 \mathrm{~g}$ sawdust, $10 \mathrm{~g} \mathrm{Mn}$ ore, $5 \%(\mathrm{v} / \mathrm{v}) \mathrm{H}_{2} \mathrm{SO}_{4}, 90^{\circ} \mathrm{C}$ and 60 minutes leaching time.

Figure 4 shows an increase in Mn content and decrease of silica and iron when the particle size (particle diameter) of the ore was decreased. EDS results revealed beneficiation of $\mathrm{Mn}$ from $24.05 \mathrm{wt} \%$ to $73.28 \mathrm{wt} \%$ at particle size of 300 mesh. Table 3 shows variation in elemental composition of $\mathrm{Mn}, \mathrm{Si}$ and $\mathrm{Fe}$ at 100, 


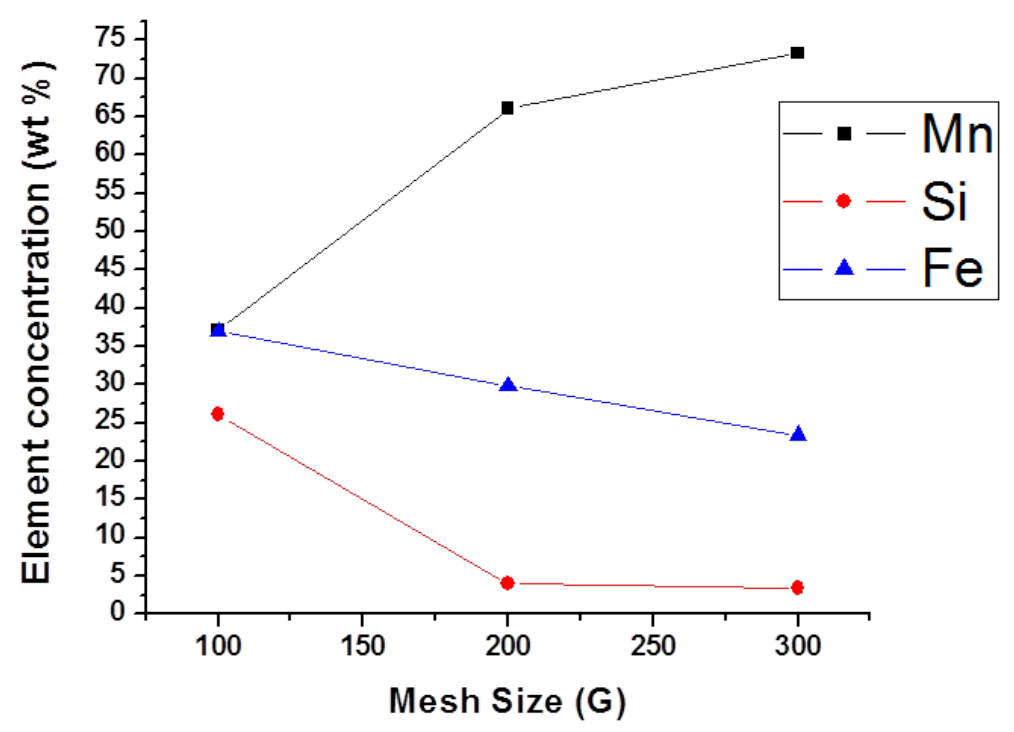

Figure 4. Variation of element concentration with mesh size.

Table 3. Elemental concentration at 100, 200 and 300 mesh size of leached Mn ore.

\begin{tabular}{cccc}
\hline \multirow{2}{*}{ Mesh size } & \multicolumn{3}{c}{ Elemental composition (wt\%) } \\
\cline { 2 - 4 } & Mn & $\mathrm{Si}$ & $\mathrm{Fe}$ \\
\hline 100 & 37.05 & 26.03 & 36.92 \\
200 & 66.11 & 4.02 & 29.87 \\
300 & 73.28 & 3.36 & 23.36 \\
\hline
\end{tabular}

200 and 300 mesh sizes of manganese ore. An increase in leaching efficiency with increasing mesh size has been reported by Hariparsad et al., and Tian et al [6] [8].

\subsection{Effect of Sawdust Amount}

Sulfuric acid cannot be used directly for leaching of manganese ores. However; reducing substances like sawdust can be used in acidic solution for high efficiency of manganese leaching.

For investigating the effect of sawdust, various leaching experiments were performed by changing sawdust concentration from 3.0 to $5.0 \mathrm{~g} / \mathrm{L}$ while keeping other parameters fix i.e. $5 \%(\mathrm{v} / \mathrm{v})$ sulfuric acid concentration, leaching time of $60 \mathrm{~min}$, manganese ore amount of $10 \mathrm{~g}$, leaching temperature of $90^{\circ} \mathrm{C}$ and mesh size of 200.

Since XRD analysis confirmed the presence of hematite phase in manganese ore sample. However; crystalline nature of hematite requires a highly acidic medium due to its consumption of $\mathrm{H}^{+}$ions. Increasing the amount of sawdust at a certain temperature and acid concentration causes an increase in the leaching efficiency of $\mathrm{Mn}$ due to excess availability of $\mathrm{H}^{+}$ion concentration [13].

Table 4 gives variation in elemental composition of $\mathrm{Mn}$, Si and Fe for 3, 4 and $5 \mathrm{~g}$ sawdust. Figure 5 shows an increase in $\mathrm{Mn}$ content accompanied by decrease 
Table 4. Elemental concentration of leached Mn-ore for $3 \mathrm{~g}, 4 \mathrm{~g}$ and $5 \mathrm{~g}$ of sawdust.

\begin{tabular}{cccc}
\hline \multirow{2}{*}{ Sawdust amount } & \multicolumn{3}{c}{ Elemental composition (wt\%) } \\
\cline { 2 - 4 } & Mn & $\mathrm{Si}$ & $\mathrm{Fe}$ \\
\hline $3 \mathrm{~g}$ & 32.82 & 10.61 & 56.57 \\
$4 \mathrm{~g}$ & 37.02 & 36.29 & 26.68 \\
$5 \mathrm{~g}$ & 66.11 & 4.02 & 29.87 \\
\hline
\end{tabular}

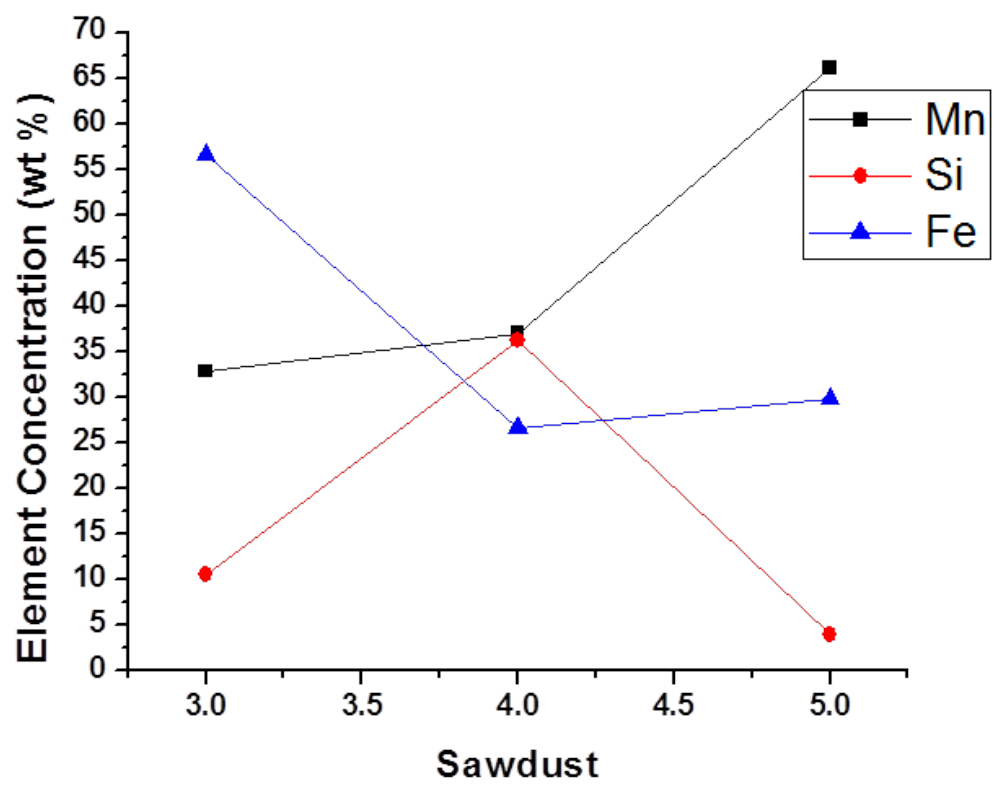

Figure 5. Efficiency of manganese ore leaching at varying amount of sawdust.

in both the Si and Fe concentrations by increasing the sawdust amount.

\subsection{Effect of Temperature on Manganese Ore Leaching}

The influence of leaching temperature on leaching efficiency at $60^{\circ} \mathrm{C}, 90^{\circ} \mathrm{C}$ and $120^{\circ} \mathrm{C}$ was investigated while keeping the other parameters constant i.e. $5 \mathrm{~g}$ sawdust, $5 \%(\mathrm{v} / \mathrm{v})$ concentration of $\mathrm{H}_{2} \mathrm{SO}_{4}$, leaching time of $60 \mathrm{~min}, 10 \mathrm{~g}$ Mn-ore of 200 mesh size.

Table 5 shows the observed variation in the elemental composition of $\mathrm{Mn}, \mathrm{Si}$ and $\mathrm{Fe}$ for manganese ore treated at $60^{\circ} \mathrm{C}, 90^{\circ} \mathrm{C}$ and $120^{\circ} \mathrm{C}$. Figure 6 shows variation in the elemental composition with temperature. The graph indicated that manganese concentration was lower at low temperature and increased with an increase in the leaching temperature; similarly the concentration of silicon and iron decreased with increasing temperature.

\subsection{Influence of Time on Leaching of Manganese Ore}

Three sets of experiments were performed in order to study the influence of time on leaching efficiency of manganese ore. The ore sample was treated for $1 \mathrm{~h}, 2 \mathrm{~h}$ and $3 \mathrm{~h}$ at constant sawdust amount $5 \mathrm{~g}$, sulfuric acid concentration $5 \%(\mathrm{v} / \mathrm{v})$, leaching temperature $90^{\circ} \mathrm{C}$ and 200 mesh size $\mathrm{Mn}$-ore $=10 \mathrm{~g}$. 
Table 5. Elemental concentration of leached Mn-ore sample at $60^{\circ} \mathrm{C}, 90^{\circ} \mathrm{C}$ and $120^{\circ} \mathrm{C}$ temperature.

\begin{tabular}{cccc}
\hline & \multicolumn{3}{c}{ Elemental composition (wt\%) } \\
\cline { 2 - 4 } Temperature & $\mathrm{Mn}$ & $\mathrm{Si}$ & $\mathrm{Fe}$ \\
\hline $60^{\circ} \mathrm{C}$ & 43.17 & 27.63 & 19.20 \\
$90^{\circ} \mathrm{C}$ & 66.11 & 4.02 & 29.87 \\
$120^{\circ} \mathrm{C}$ & 88.93 & 2.12 & 8.95 \\
\hline
\end{tabular}

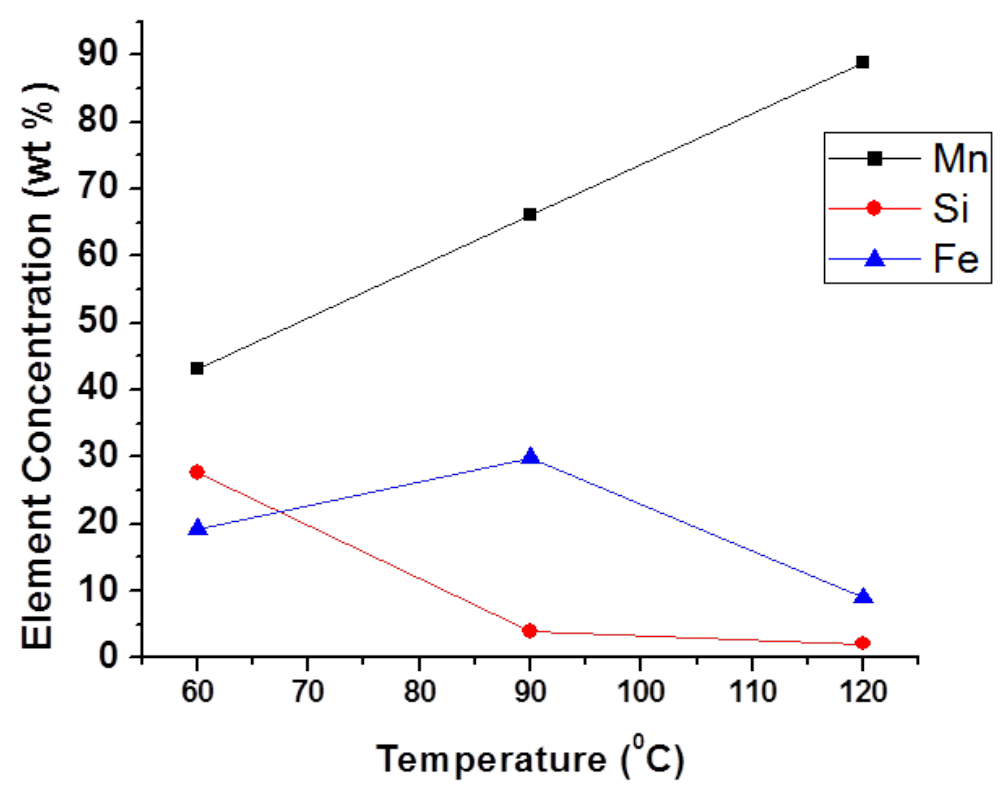

Figure 6. Effect of temperature on elemental concentration of the samples.

Table 6. The elemental concentration of Mn ore sample leached at $1 \mathrm{~h}, 2 \mathrm{~h}$ and $3 \mathrm{~h}$.

\begin{tabular}{cccc}
\hline \multirow{2}{*}{ Time } & \multicolumn{3}{c}{ Elemental composition } \\
\cline { 2 - 4 } & $\mathrm{Mn}$ & $\mathrm{Si}$ & $\mathrm{Fe}$ \\
\hline $1 \mathrm{~h}$ & 66.11 & 4.02 & 29.87 \\
$2 \mathrm{~h}$ & 74.11 & 8.24 & 17.65 \\
$3 \mathrm{~h}$ & 83.35 & 6.61 & 10.04 \\
\hline
\end{tabular}

Table 6 gives the quantitative variation in the elemental concentration of $\mathrm{Mn}$, $\mathrm{Si}$ and Fe. Figure 7 shows the graph for variation in elemental concentration of the leached samples with change in leaching time. It was observed that by increasing time duration from $1-3 \mathrm{~h}$ the recovery increased from 66 to $83 \mathrm{wt} \%$, consistent with the previous study.

\subsection{Effect of Manganese Ore Amount}

Leaching experiments were also performed for $10 \mathrm{~g}, 15 \mathrm{~g}$ and $20 \mathrm{~g} 200$ mesh $\mathrm{Mn}$ ore samples at fixed values of $5 \%(\mathrm{v} / \mathrm{v}) \mathrm{H}_{2} \mathrm{SO}_{4}, 5 \mathrm{~g}$ sawdust, $90^{\circ} \mathrm{C}$ temperature and $1 \mathrm{~h}$ leaching time. 


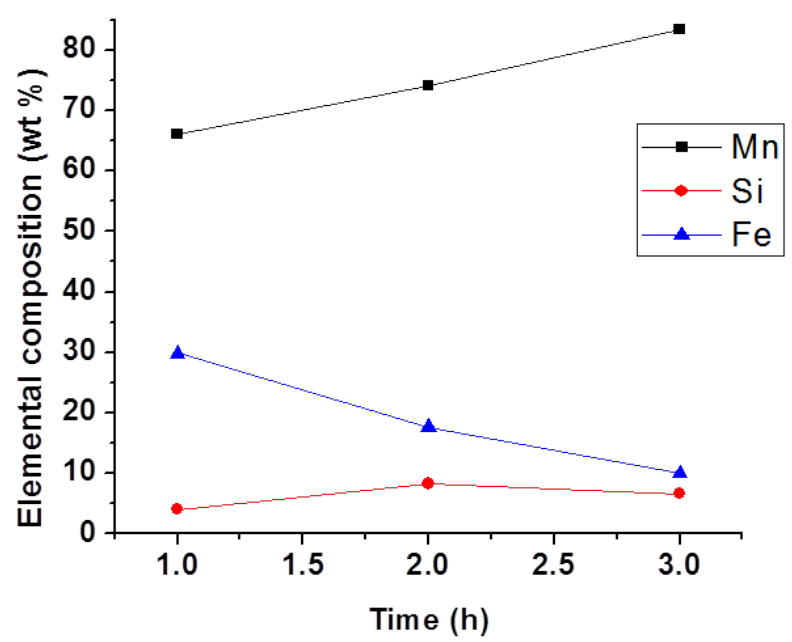

Figure 7. Effect of leaching time on the elemental concentration of Mn-ore.

Table 7. The elemental concentration of $10 \mathrm{~g}, 15 \mathrm{~g}$ and $20 \mathrm{~g}$ Mn ore sample.

\begin{tabular}{cccc}
\hline \multirow{2}{*}{ Ore amount } & \multicolumn{3}{c}{ Elemental composition } \\
\cline { 2 - 4 } & $\mathrm{Mn}$ & $\mathrm{Si}$ & $\mathrm{Fe}$ \\
\hline $10 \mathrm{~g}$ & 66.11 & 4.02 & 29.87 \\
$15 \mathrm{~g}$ & 68.71 & 14.49 & 16.79 \\
$20 \mathrm{~g}$ & 62.44 & 11.78 & 25.78 \\
\hline
\end{tabular}

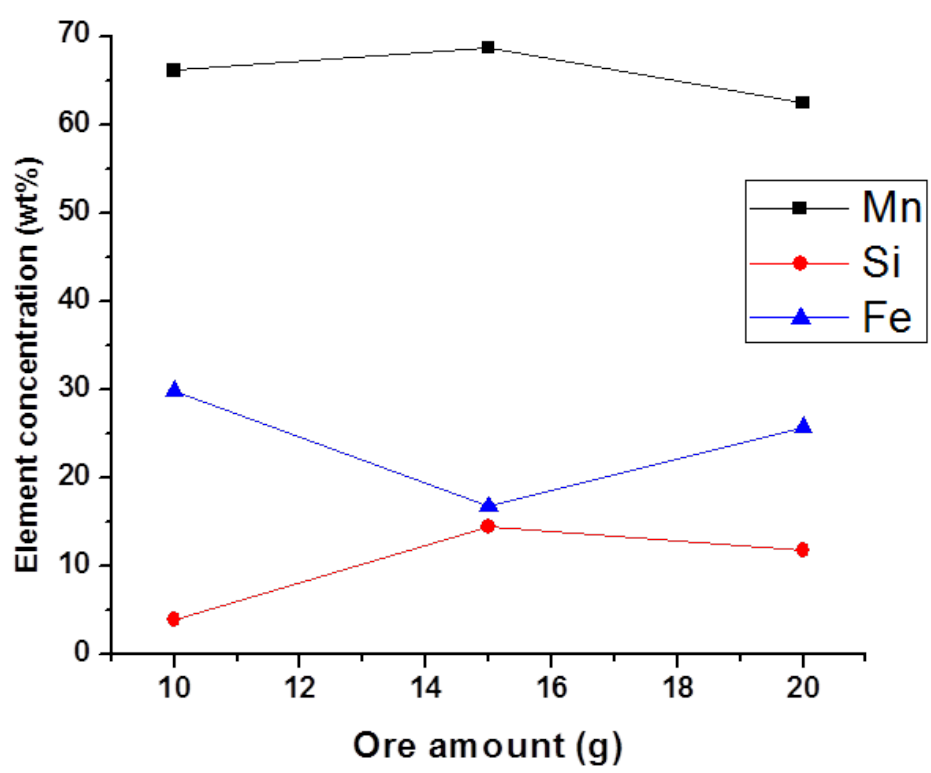

Figure 8. Effect of ore amount on the elemental concentration of leached Mn-ore samples.

Table 7 gives the elemental and oxide compositions of $\mathrm{Mn}, \mathrm{Si}$ and Fe for 10, 15 and $20 \mathrm{~g}$ of Mn ore.

Figure 8 shows the observed variation in the elemental concentration of $\mathrm{Mn}$, $\mathrm{Si}$ and Fe. These experiments demonstrated that by increasing the manganese ore amount the concentration of manganese decreased which may be due to in- 
sufficient amount of acid or the reducing sugar generated from the smaller amount of sawdust in comparison to the ore amount.

\subsection{Effect of $\mathrm{H}_{2} \mathrm{SO}_{4}$ Concentration}

The influence of the amount of acid used on the leaching efficiency was also investigated. $5 \mathrm{~mL}, 10 \mathrm{~mL}$ and $15 \mathrm{~mL} \mathrm{H}_{2} \mathrm{SO}_{4}$ was used for $5 \mathrm{~g}$ sawdust, at $90^{\circ} \mathrm{C}$ leaching temperature, with a leaching time of $60 \mathrm{~min}$ and 200 mesh size $10 \mathrm{~g} \mathrm{Mn}$ ore sample.

Table 8 gives elemental concentration and oxide compositions of $\mathrm{Mn}, \mathrm{Si}$ and Fe measured by EDS for manganese ore treated with $5 \mathrm{~mL}, 10 \mathrm{~mL}$ and $15 \mathrm{~mL}$ $\mathrm{H}_{2} \mathrm{SO}_{4}$. Figure 9 shows the observed variation in elemental composition with acid concentration. EDS analysis showed that the leaching efficiency increased with an increase in the amount of acid used because the sawdust released glucose more rapidly than at relatively less acid.

\section{Conclusions}

In this study, manganese ore from Prang Ghar, Lower Mohmand agency, Pakistan was characterized using XRD, SEM, EDX and optical microscopy. Prang Ghar manganese ore is a low grade ferruginous manganese ore. The major non-

Table 8. Elemental concentration of $\mathrm{Mn}$ ore leached with $5 \mathrm{~mL}, 10 \mathrm{~mL}$ and $15 \mathrm{~mL} \mathrm{H}_{2} \mathrm{SO}_{4}$.

\begin{tabular}{cccc}
\hline & \multicolumn{3}{c}{ Elemental composition (wt\%) } \\
\cline { 2 - 4 } $\mathrm{H}_{2} \mathrm{SO}_{4}$ concentration & $\mathrm{Mn}$ & $\mathrm{Si}$ & $\mathrm{Fe}$ \\
\hline $5 \mathrm{~mL}$ & 66.11 & 4.02 & 29.87 \\
$10 \mathrm{~mL}$ & 76.21 & 16.19 & 7.61 \\
$15 \mathrm{~mL}$ & 80.77 & 8.63 & 10.60 \\
\hline
\end{tabular}

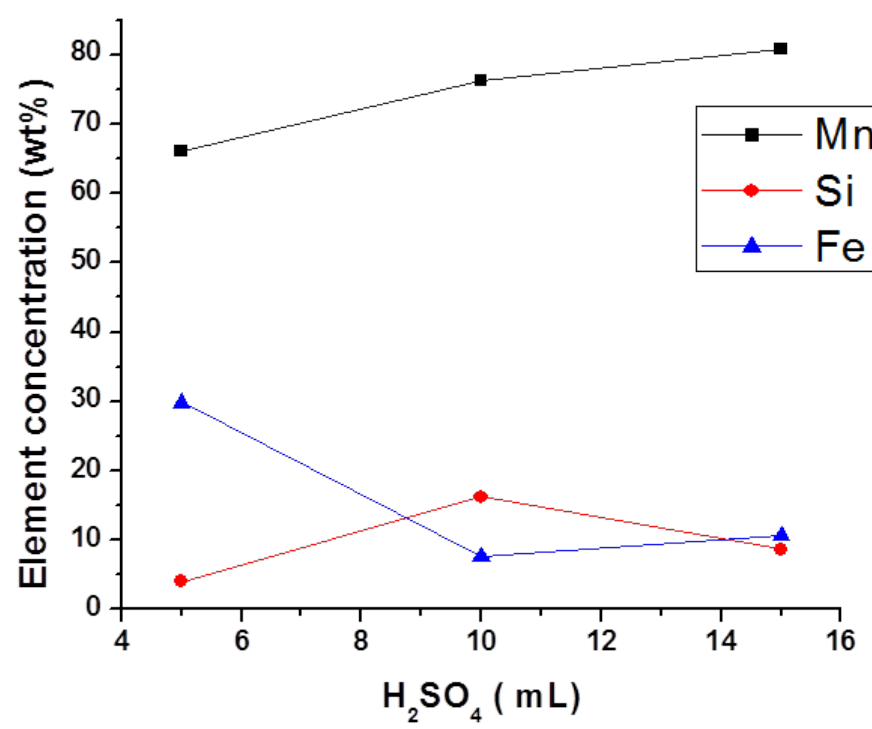

Figure 9. Effect of the amount of acid on the elemental concentration in the leached samples. 
oxide elements detected by EDS in this ore are Manganese, Silicon and Iron. The mineralogy of manganese ore is complex. The constituent phases of manganese ore samples identified using XRD analysis are Hausmannite $\left(\mathrm{Mn}_{3} \mathrm{O}_{4}\right)$, Calcium Aluminum Silicate Hydrate, Silica $\left(\mathrm{SiO}_{2}\right)$ and Hematite.

The chemical beneficiation of manganese ore was carried out using a commercial grade concentrated $\mathrm{H}_{2} \mathrm{SO}_{4}$ and sawdust as reductant. The investigated parameters included temperature; $\mathrm{Mn}$ ore mesh size and amount, leaching time, acid concentration and sawdust amount. The highest manganese concentration of 88.93 (wt\%) was achieved at $120^{\circ} \mathrm{C}, 200$ mesh size Mn ore, 60 minutes leaching time, $5 \%(\mathrm{v} / \mathrm{v}) \mathrm{H}_{2} \mathrm{SO}_{4}$ and $5 \mathrm{~g}$ sawdust. Mn extraction increases with an increase in temperature, ore particle size, sawdust amount, time duration and the amount of acid. The observed decrease in Mn concentration with increasing Mn ore amount may be due to insufficient amount of acid or the reducing sugar generated from the sawdust. In all the experiments, the decrease in Si and Fe has been observed with increase in all the six parameters. Considering the observed productivity of the utilized sawdust, the process is beneficial from both the economic and environmental perspective.

\section{Acknowledgements}

The authors highly appreciate and acknowledge the financial support of the Higher Education Commission, Pakistan and the US National Academy of Science under the Pak-US S\&T Cooperation Program for Materials Connection Center. We also admire and thanks for the financial support of Khyber Pukhtunkhwa Government through the pilot research studies program of the Directorate of Science \& Technology, KP for extension in Mineral Up-gradation Pilot Plant and Up-gradation of Materials Research Laboratory, University of Peshawar.

\section{References}

[1] Sahoo, R.N., Naik, P.K. and Das, S.C. (2001) Leaching of Manganese Ore Using Oxalic Acid as Reductant in Sulphuric Acid Solution. Hydrometallurgy, 62, $157-$ 163. https://doi.org/10.1016/S0304-386X(01)00196-7

[2] Sahoo, P.K. and Rao, K.S. (1989) Sulphating-Roasting of Low Grade Manganese Ore Optimisation by Factorial Design. International Journal of Mineral Processing, 25, 147-152. https://doi.org/10.1016/0301-7516(89)90061-6

[3] Abbruzzese, C. (1987) Aqueous $\mathrm{SO}_{2}$ Processing of Manganese Ores Separation Processes in Hydrometallurgy. Ellis Horwood Ltd., 77-87.

[4] Pagnanelli, F., Furlani, G., Valentini, P., Veglio, F. and Toro, L. (2004) Leaching of Low-Grade Manganese Ores by Using Nitric Acid and Glucose Optimization of the Operating Conditions. 157-167.

[5] Kelong, Y.Y.H. (2001) Test of Pyrolusite Direct Leaching in Sulphuric Acid with Addition of Plants Powder as Reducing Agents.

[6] Hariparsad, D., Dash, B., Ghosh, M.K. and Anand, S. (2007) Leaching of Manganese Ore Using Sawdust as a Reductant. 1293-1295.

[7] Lasheen, T.A., El-Hazek, M.N., Helal, A.S. and El-Nagar, W. (2009) Recovery of 
Manganese Using Molasses as Reductant in Nitric Acid Solution. International Journal of Mineral Processing, 92, 109-114.

https://doi.org/10.1016/j.minpro.2009.03.001

[8] Tian, X., Wen, X., Yang, C., Liang, Y., Pi, Z. and Wang, Y. (2010) Reductive Leaching of Manganese from Low-Grade Manganese Dioxide Ores Using Corncob as Reductant in Sulfuric Acid Solution. Hydrometallurgy, 100, 157-160.

https://doi.org/10.1016/j.hydromet.2009.11.008

[9] Zhang, H., Zhu, G., Yan, H., Zhao, Y., Li, T. and Feng, X. (2013) Reduction of Low-Grade Manganese Dioxide Ore Pellets by Biomass Wheat Stalk. Acta Metallurgica Sinica, 26, 167-172. https://doi.org/10.1007/s40195-012-0250-X

[10] Cheng, Z., Zhu, G. and Zhao, Y. (2009) Study in Reduction-Roast Leaching Manganese from Low-Grade Manganese Dioxide Ores Using Cornstalk as Reductant. Hydrometallurgy, 96, 176-179. https://doi.org/10.1016/j.hydromet.2008.08.004

[11] Su, H., Wen, Y., Wang, F., Sun, Y. and Tong, Z. (2008) Reductive Leaching of Manganese from Low-Grade Manganese ore in $\mathrm{H}_{2} \mathrm{SO}_{4}$ Using Cane Molasses as Reductant. Hydrometallurgy, 93, 136-139.

https://doi.org/10.1016/j.hydromet.2008.01.001

[12] Van der, W., Mahabir, R.D., Abbadi, J. and Reuter, M.A. (2002) Copper Recovery from $\mathrm{Cu}$ Sulphate Solutions by Reduction with Carbohydrates. Hydrometallurgy, 64, 131-146.

[13] Momade, F.W.Y. and Momade, Zs.G. (1999) Reductive Leaching of Manganese Ore Inaqueous Methanol-Sulphuric Acid Medium. Hydrometallurgy, 51, 103-113. https://doi.org/10.1016/S0304-386X(98)00077-2 